\title{
PHOTOLINEARS, FRACTURES, AND FALLACIES: A POST HOC STUDY OF PHOTOLINEAMENTS, HILLSBOROUGH COUNTY, FLORIDA
}

\author{
Michael C. Alfieri \\ Water Resource Associates, LLC, 4260 West Linebaugh Avenue, Tampa, Florida 33624, USA, \\ Malfieri@wraengineering.com \\ Sam B. Upchurch \\ SDII Global Corporation, 4509 George Rd, Tampa, Florida 33634,USA, flwaterdoc@gmail.com
}

Thomas L. Dobecki

Dobecki Geosciences, LLC, 3414 West Sutton Drive, Mishawaka, Indiana, 46545, USA, dobecki@yahoo.com

\begin{abstract}
There is a misconception by some in the geologic and non-geologic communities of Florida that photolineaments and vertical bedrock fractures are one and the same. The main objectives of this paper are (1) to document a case study where a comprehensive geophysical and geotechnical exploration program was undertaken to verify a high-quality photolinear analysis; and, based on the case study, (2) evaluate the validity of photolinears as indicators of vertical bedrock fractures in the covered karst terrain of west-central Florida. The case study, an investigation by Upchurch et al. (1999), was an analysis of photolineaments at a 445-ha site intended for construction of an above-grade reservoir in west-central Florida. The photolineaments were ground truthed using ground penetrating radar (GPR), refraction and reflection seismic profiling, standard penetration testing (SPT), and cone penetrometer testing (CPT; Dobecki and Upchurch 2010).
\end{abstract}

The post hoc review, based on the comprehensive site geophysical and geotechnical testing and resulting data, determined that fifty-eight percent of the photolinears do not correspond to vertical fractures in the limestone bedrock. This review demonstrates the fallacies of assuming all photolinears represent vertical bedrock fractures in the covered karst terrain of west-central Florida. Based on this case study and the post hoc review, it is our belief that in the covered karst terrains of Florida, all photolinear evaluations should have some form of field verification in order to equate them to vertical bedrock fractures or karst features.

\section{Introduction}

Regional and local photolineament analyses are valuable as a first approximation of the possible presence of bedrock structures such as vertical fractures in covered karst (Lattman 1958; Lattman and Matzke 1961;
Lattman and Parizek 1964; and Littlefield et al. 1984). However, like any other tool, there is a potential for misuse of photolineament analyses, which can lead to potential errors and misinterpretations of actual geologic conditions (Wheeler 1983). In other karst regions of the world where the carbonate bedrock is thinly covered (less than 3 meters) by regolith or is bare, there is a higher correlation between photolinears and vertical bedrock fractures. However, this degree of correlation does not exist in the sinkhole prone, covered karst terrain of westcentral Florida, where cover thicknesses are upwards of 15 or more meters.

Work completed by Littlefield et al. (1984) has indicated that sinkholes tend to preferentially occur on fracture traces (verified photolineaments) and at fracture trace intersections in Florida. The problem with many photolineament analyses completed in Florida is that verification testing is rarely completed or minimally done to prove that the photolineaments correlate with true vertical fractures in the bedrock. Furthermore, verification testing is rarely completed or minimally done to prove differences in the surrounding area in lithology, structure, hydraulic conductivity, or some other geologic property that suggests a vertical linear feature in the bedrock. The authors are only aware of one large-scale photolineament analysis in Florida wherein all of the photolinears were specifically and comprehensively ground truthed via geophysics and geotechnical testing.

\section{A Case Study of a "Ground Truthed" Photolineament Assessment Study}

Upchurch et al. (1999) was a comprehensive analysis of photolineaments at the then proposed C.W. Bill Young (Tampa Bay Regional) Reservoir site (Figure 1) in Hillsborough County, Florida. The proposed reservoir site was specifically located in an area of a relatively thick sequence of clay-rich Miocene strata, which 
forms the aquitard between the surficial aquifer and Floridan aquifer. This location was thought to minimize risks associated with potential sinkhole formation and excessive reservoir leakage. A generalized stratigraphic column with representative unit thickness is presented on Figure 2.

A number of sinkhole studies, which were based on topographic analysis to identify areas with closed drainage, were conducted in the area and indicated numerous sinkholes to the northwest of the project site (Littlefield et al. 1984; Upchurch and Littlefield 1987 1988). Based on this knowledge and knowing that sinkholes tend to preferentially occur on fracture traces and at fracture trace intersections in Florida, it was decided during the planning and design phase of the project that a comprehensive karst geologic investigation, including photolinear interpretation, should be completed to provide reasonable assurances that the reservoir footprint was not in an area of elevated sinkhole risk or having the potential for excessive leakage.

\section{Regional Geologic Setting}

The study site is located within the Polk Upland Physiographic Province of Florida (Puri and Vernon, 1964). Land surface elevations range from approximately 21 to 30 meters above sea level (m ASL). The land surface is flat to gently sloping.

Three major geologic units occur at or near the land surface. They are, in order of youngest to oldest, undifferentiated Plio-Pleistocene marine terrace deposits, the Miocene Peace River Formation and the Miocene Arcadia Formation (Hawthorn Group; Scott 1988 and Scott et al. 2001). A generalized stratigraphic column with representative unit thickness is presented on Figure 2.

The Plio-Pleistocene marine terrace deposits consist of approximately 1 to $9 \mathrm{~m}$ of fine to medium, well sorted sand. Scattered, small lenses of clay are present, and the sand mantle is thickest in buried, relict sinkholes.

The Miocene Hawthorn Group (Figure 2) includes the Peace River Formation (Scott 1988). The Peace River includes an upper member, the Bone Valley Member, that generally consists of sand-sized and larger phosphorite grains set in a matrix of poorly consolidated sand, silt, and/or clay. The lithology of the unit is highly variable, and lateral and vertical facies changes can be abrupt. The remainder of the underlying Peace River Formation is a mixed clastic-carbonate unit composed of interbedded quartz sand, clay and dolostone. The quartz sand is clayey, fine to medium grained, and poorly consolidated.
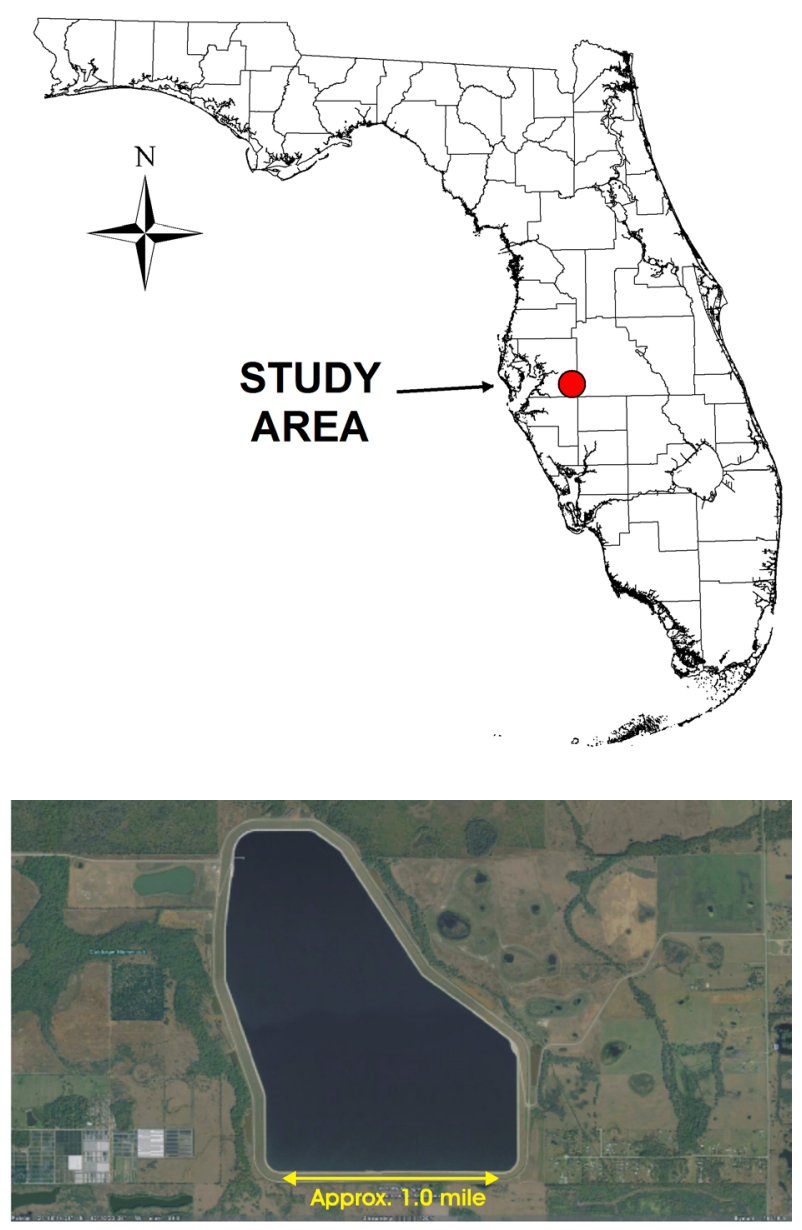

Figure 1. C.W. Bill Young (Tampa Bay Regional) Reservoir site, Hillsborough County, Florida. Aerial photograph from Google Earth (2017).

The clay in the Peace River Formation may be sandy, silty, calcareous, or dolomitic, and poorly to moderately consolidated. The dolostone is typically sandy, clayey, micro to fine crystalline (dolosilt), and poorly to moderately indurated. Peace River sediments range from approximately 15 to $30 \mathrm{~m}$ in thickness and overlie older Miocene deposits that are typically less than $100 \mathrm{~m}$ thick.

The Arcadia Formation underlies the Peace River Formation throughout the region (Scott 1988 and Scott et al. 2001). The upper, undifferentiated Peace River Formation consists of interbedded sand, clay, and carbonate strata. In contrast to the Peace River Formation, the Arcadia is more carbonate rich, with widespread dolostone and limestone layers and lenses. The base of the Arcadia includes a sandy, sometimes phosphatic limestone known as the Tampa Member of the Arcadia Formation. The Tampa Member is typically limestone that is moderately sandy, clayey, and locally may contain lenses of green and gray clayey sand, sandy 


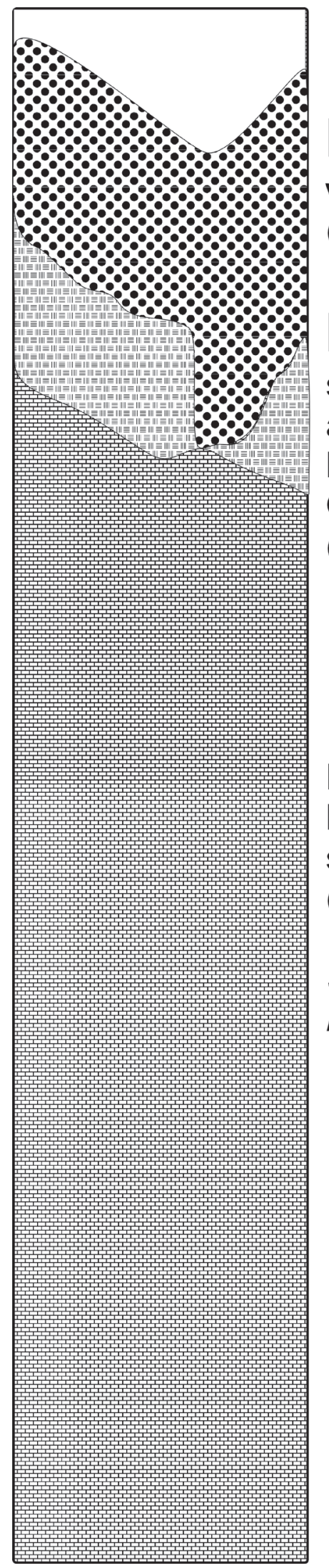

Pleistocene marine terrace deposit, Fine sand with minor clay

$(1-9 \mathrm{~m}$; median thickness $=5 \mathrm{~m})$

Plio-Pleistocene paleosol. Sand with clay to sandy clay, minor phosphate, and common aluminum phosphate minerals; informally known as the "leached zone" in the Central Florida Phosphate Mining District $(0-12 \mathrm{~m}$; median thickness $=4 \mathrm{~m})$

Miocene Hawthorn Group. Complex mixture of limestone, dolostone, clay, and sand lithofacies; sparse to abundant phosphate $(100+m$ thick $)$

See Figure 13 for the pattern of lithofacies interfingering

Figure 2. Generalized stratigraphic column showing stratigraphy and relative unit thicknesses at the C.W. Bill Young (Tampa Bay Regional) Reservoir site, Hillsborough County, Florida. 
clay and chert. Near the site, the Tampa Member is found at depths greater than $61 \mathrm{~m}$ below land surface (BLS).

After deposition of the Miocene strata, a major unconformity formed that is characterized by a welldeveloped paleosol locally known as the "leached zone" (Figure 2). The leached zone is characterized by relict stream channels, in-filled, Mio-Pliocene-aged sinkholes, and an irregular surface, all of which are at least partly masked by the overlying Plio-Pleistocene marine terrace deposits.

\section{Photolinear Analysis and Comprehensive Geophysical and Geotechnical Investigation}

Figure 3 depicts a pre-construction aerial photograph of the reservoir site with an overlay of interpreted photolinear features by Upchurch et al. (1999). Photolinears were tentatively identified on USDA aerial photographs from six different years. The colors of lines on Figure 3 reflect confidence ranking of the photolinear.

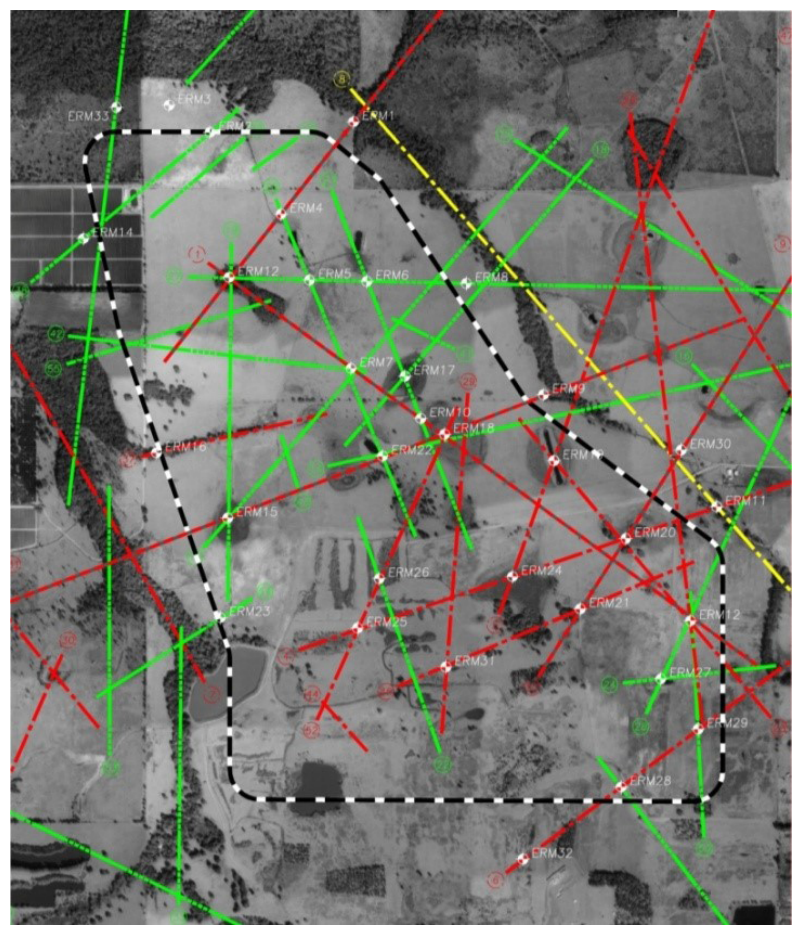

Figure 3. Pre-development aerial photograph of the C.W. Bill Young Reservoir site near Tampa, Hillsborough County, Florida showing photolineaments ranked by confidence. Dashed line is the center line of the proposed $91 \mathrm{~m}$ wide reservoir berm. Red lines represent highest confidence, while yellow reflects lowest.
Red lines represent highest confidence, while yellow reflects lowest.

Areas for geological testing within the reservoir footprint were selected based on the photolinear analysis. Photolinear intersections, high and medium confidence photolinears, and apparent sinkhole features were subjected to geophysical testing. In addition, the proposed location of the berm surrounding the reservoir was subjected to extensive geophysical exploration.

Acquisition of GPR data covering large areas of the reservoir project, including traverses along the centerline of the entire embankment plus parallel lines approximately $30 \mathrm{~m}$ to each side of the centerline, were collected. Gridded (areal) coverage over areas of interest defined by the analysis of the photolinears was also acquired. In total, approximately $47.6 \mathrm{~km}$ of GPR profiling was acquired across the property (Figure 4). An example of an identified site GPR anomaly is presented on Figure 5.

Prior geologic investigations by the authors had identified the presence of a cemented sand layer at a depth of approximately 9 to $12 \mathrm{~m} \mathrm{BLS}$, which is over twice as deep as the GPR signal could reach. This

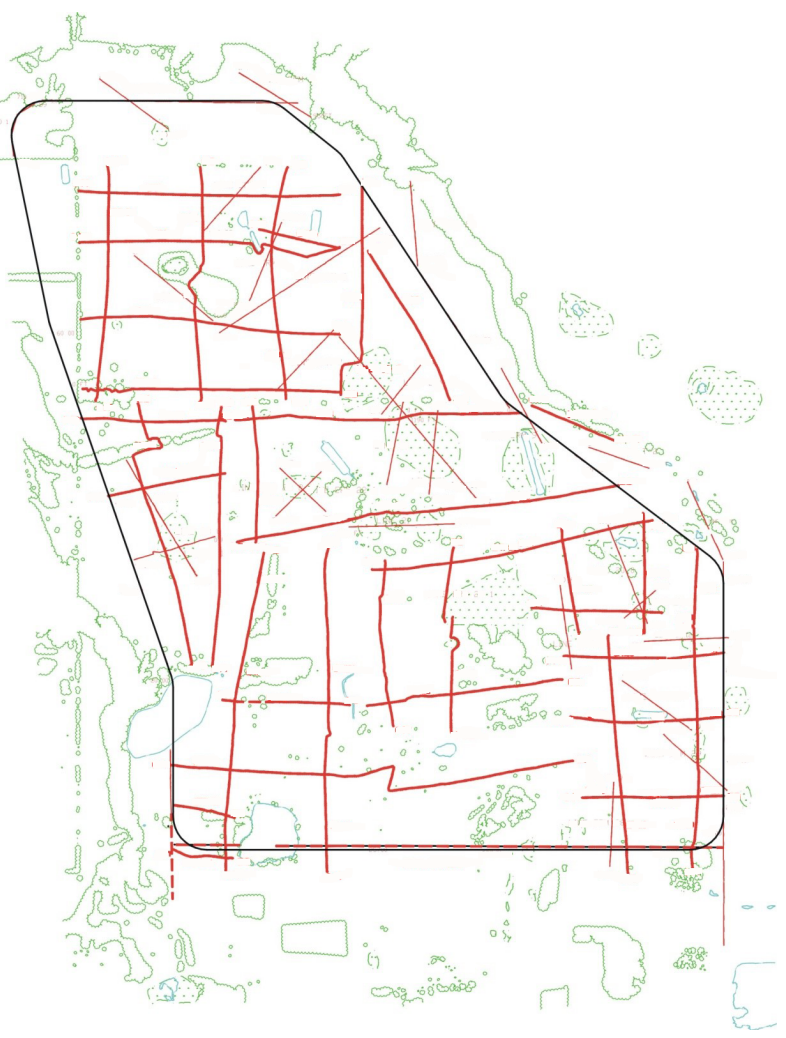

Figure 4. Location of ground penetrating radar survey lines (Upchurch et al. 1999). 


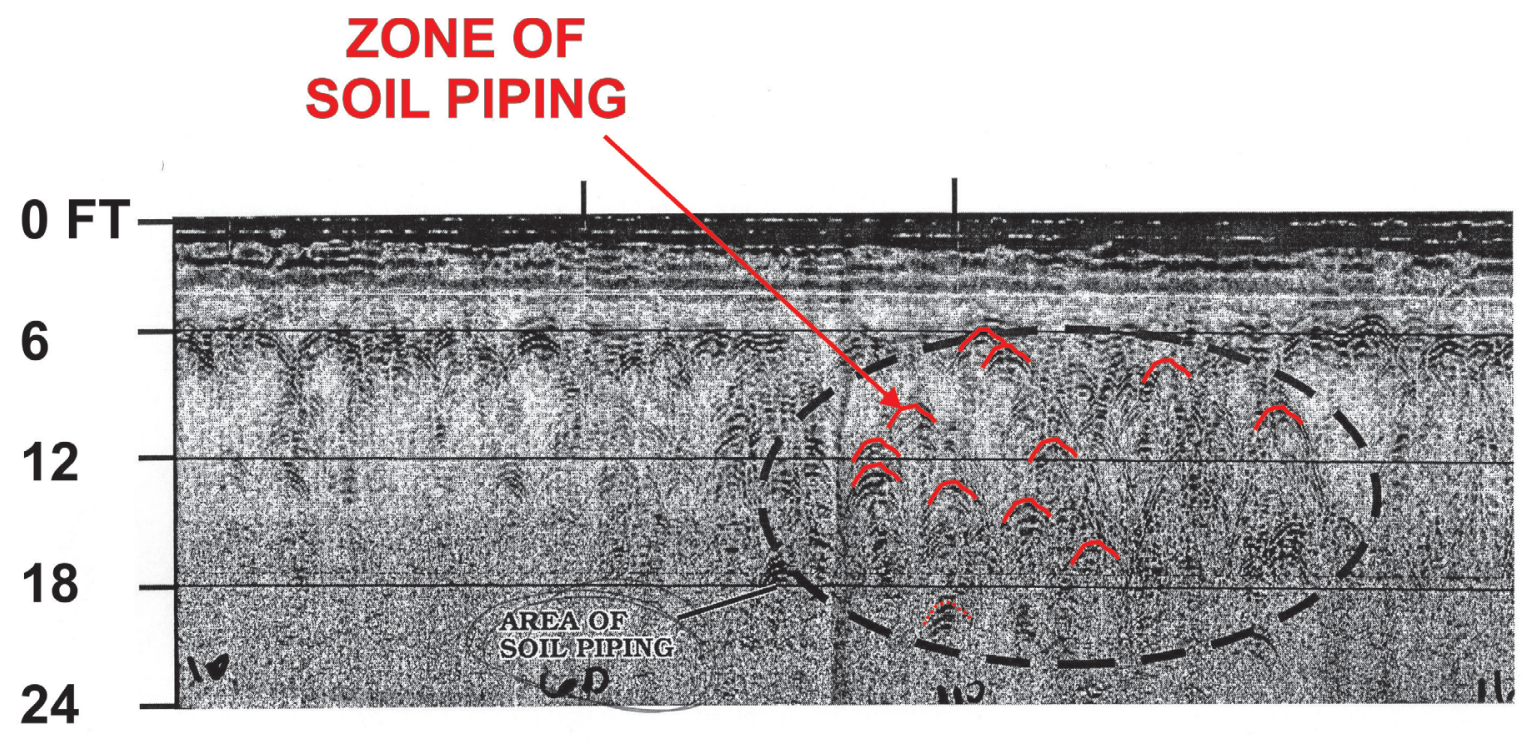

\section{ANOMALOUS GPR PROFILE}

Figure 5. Example GPR profile showing shallow anomaly zone (Upchurch et al. 1999).

layer, which is a hard layer within the leached zone and below the water table, offered the potential of providing a surface that could reflect potential down warping, raveling, or sinkhole development. Seismic refraction was selected as the test method to track this layer, as it is an effective tool for mapping interfaces where a harder layer underlies a softer layer. Seismic shear (S) waves were selected over the compression $(\mathrm{P})$ wave technique, because of the level of contrast between the shallower/ softer soils and the cemented layer. All major GPR anomalies were tested using refraction profiling.

Preliminary testing of $\mathrm{P}$ versus $\mathrm{S}$ wave refraction showed that the $\mathrm{P}$ wave velocity of the cemented layer was approximately 15 to 20 percent higher than the loose soils above. The $\mathrm{S}$ wave velocity contrast, however, was nearly 300 percent higher in the cemented layer than in the looser shallow soils. This is to be expected below the water table where the $\mathrm{P}$ wave velocity of all layers jumps due to water saturation. The shear wave velocity has almost no response to full water saturation, as it expresses contrast between the matrix of the soils and the degree of cementation. The high contrast using $\mathrm{S}$ waves led to more precise interpretations of the resulting refraction data. All major GPR anomalies were tested using refraction profiling. The entire berm length was also surveyed using $\mathrm{S}$ wave refraction because material strength and continuity beneath the berm is such an important factor. In total, approximately $21.9 \mathrm{~km}$ of shear wave seismic refraction profiling was acquired across the site (Figure 6).

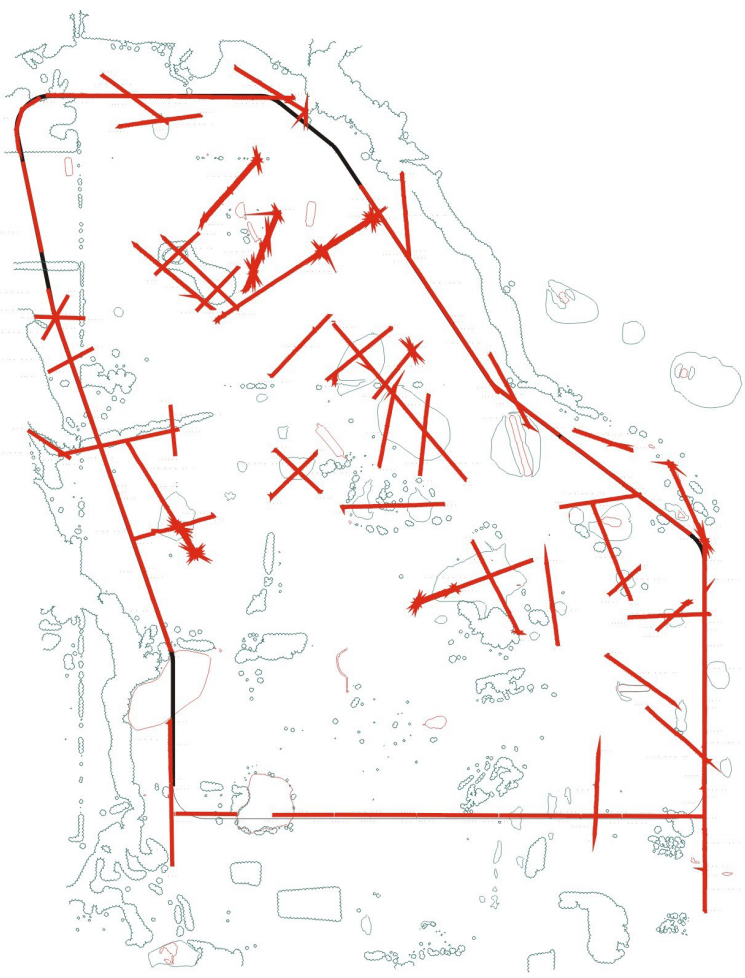

Figure 6. Location of seismic refraction lines (Upchurch et al. 1999).

Figures $7 \mathrm{a}$ and $7 \mathrm{~b}$ are plots of a raw shot record -24 channels, SH geophones/SH hammer source with a $3 \mathrm{~m}$ geophone spacing. The raw data show three clear velocity arrivals. Figures $8 \mathrm{a}$ and $8 \mathrm{~b}$ depict an interpreted 
seismic refraction profile in an area where the deepest (cemented) layer exhibits an approximately $6 \mathrm{~m}$ depression. The typical layer parameters are:

- Layer 1; Vs $=107 \mathrm{~m} / \mathrm{sec}$; surficial (disturbed) soil;

- Layer 2; Vs $=271 \mathrm{~m} / \mathrm{sec}$; compacted sands and clays; and

- Layer 3; Vs $=736 \mathrm{~m} / \mathrm{sec}$; cemented layer.

Such anomalies were tracked and mapped and then they were scheduled for more detailed analysis using high-

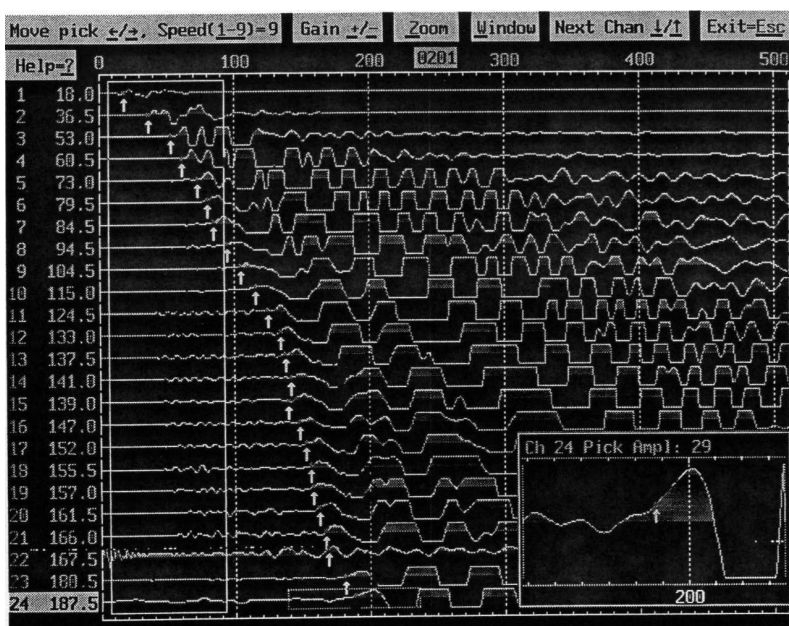

Figure 7a. Site example of a raw shot record (Upchurch and Dobecki, 2010). resolution seismic reflection, geotechnical borings, or both.

Areas that were characterized by photolinears, GPR anomalies, and refraction depression anomalies were deemed to be potential karst or fracture features that required deeper and more detailed investigation. These types of anomaly combinations were surveyed using high-resolution seismic reflection surveying. Testing consisted of a 24-channel seismograph, 12-fold acquisition procedures with $1.5 \mathrm{~m}$ shot and geophone spacing, and an 8-gauge Betsy Seisgun source fired

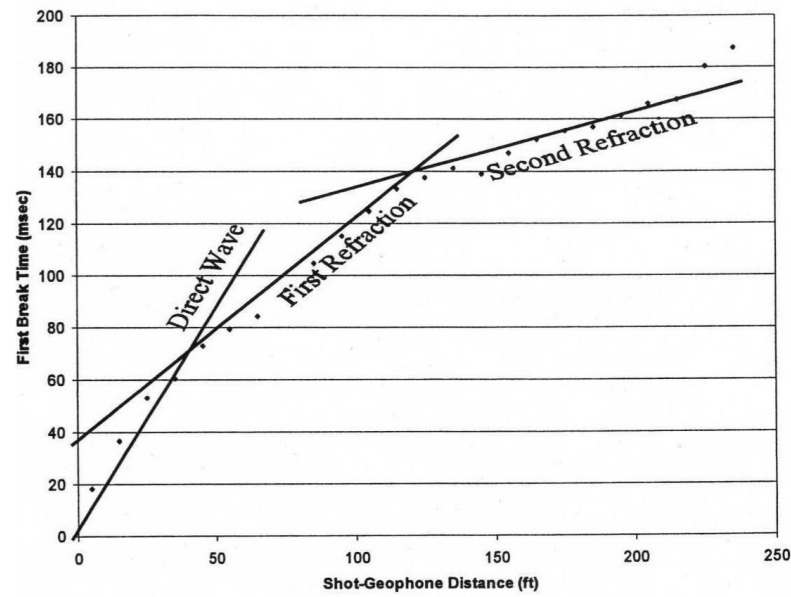

Figure $\mathbf{7 b}$. Site example of a refraction travel time curve (Upchurch and Dobecki, 2010).

\section{Berm Refraction Line 80}

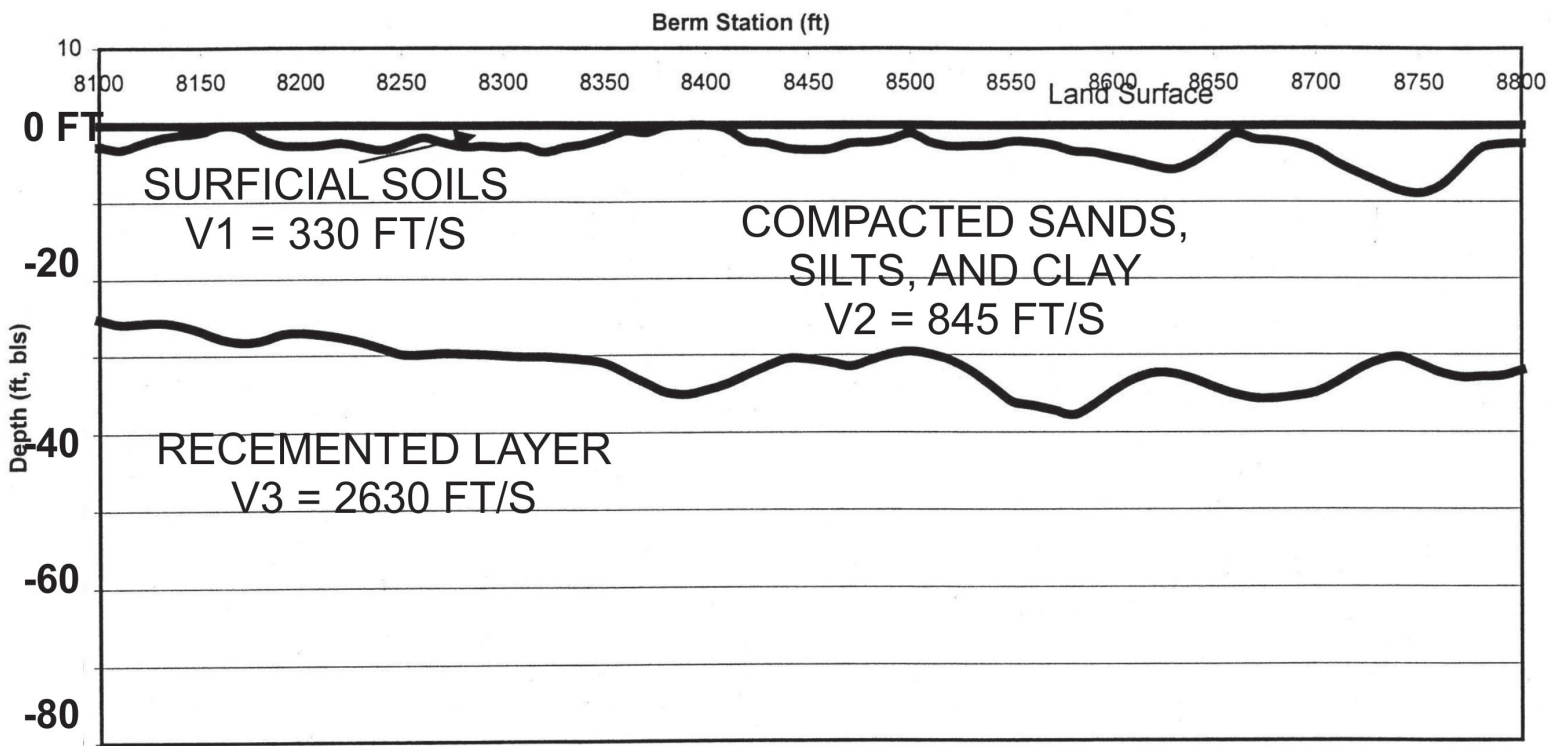

Figure 8a. Example of an interpreted $S$ wave refraction cross section showing a typical section (Upchurch and Dobecki, 2010). 


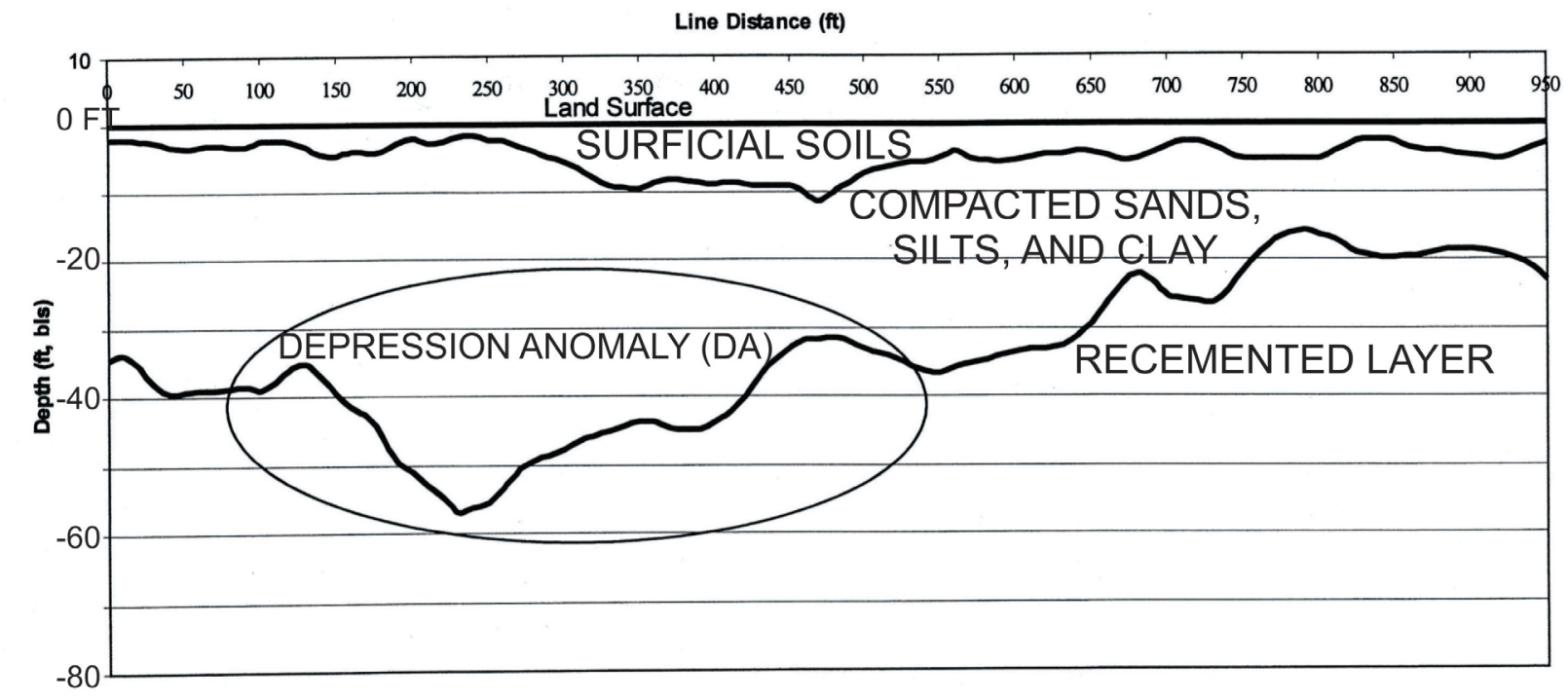

Figure $8 \mathbf{b}$. Example of an interpreted $S$ wave refraction cross section showing a depression anomaly (circled; Upchurch and Dobecki, 2010).

within a shallow augered hole. Approximately $5.2 \mathrm{~km}$ of high resolution seismic reflection profiling were acquired across the property (Figure 9).

Figure 10 is a sample processed seismic reflection section that was acquired across shallow radar and refraction anomalies. The dashed line near $0.03 \mathrm{sec}$ is the interpreted top of the dolostone layer. We have circled two anomalous areas where there is a loss of continuity of the dolostone reflection and where there is a depressed and down warped appearance of that reflection. We also show the location of two SPT borings that were drilled at the locations of maximum disruption as seen on the reflection section. The results of these explorations are discussed in the following section.

\section{Subsurface Geological Testing}

SPT borings and CPT soundings, as well as selected rock coring, were completed in identified geophysical anomalies (Figure 11) and along the proposed berm and reservoir bottom to (1) verify geologic conditions for geophysical interpretation and (2) identify potentially active karst features. In all, more than 5.6 $\mathrm{km}$ of subsurface testing were completed as part of the geotechnical investigation at the site and included approximately $1.6 \mathrm{~km}$ of $\mathrm{H}$ and $\mathrm{P}$-size rock coring (Table 1).

Rock core recovery was highly variable across the site with recoveries ranging from 60 to 70 percent. This is a high level of recovery for the unconsolidated and poorly cemented strata of the area. The subsurface testing locations are presented on Figure 12.

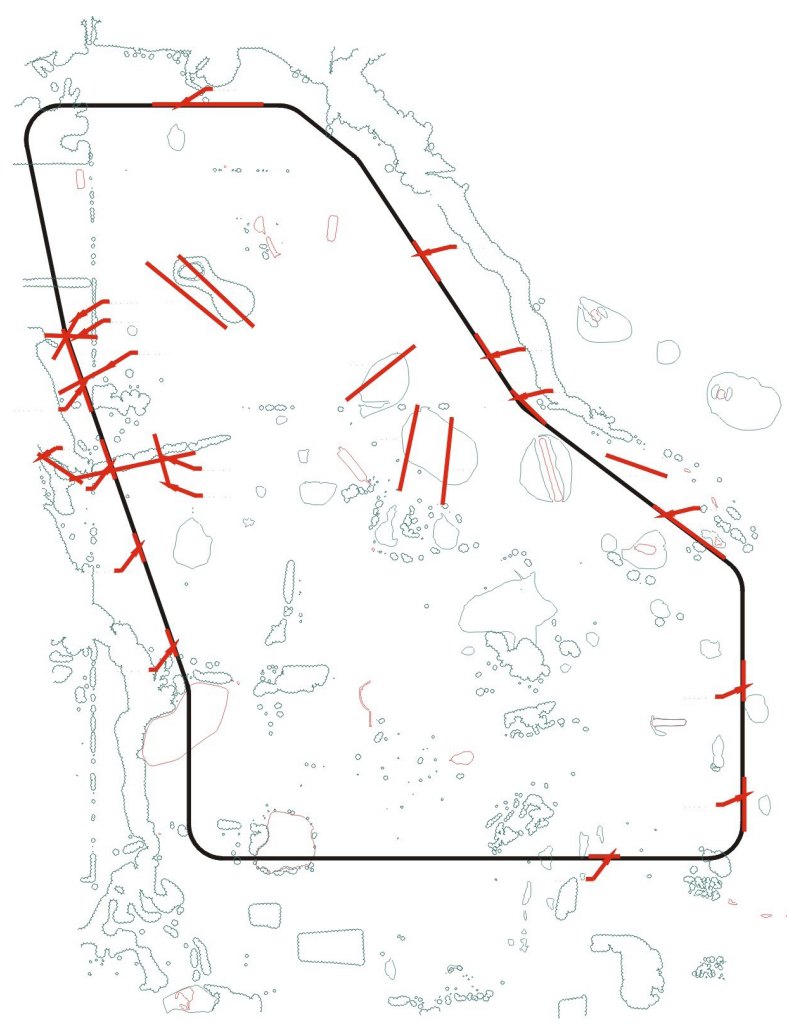

Figure 9. Location of seismic reflection lines (Upchurch et al. 1999).

Geologic formations were identified based on lithology. However, the upper 30.5 to $46 \mathrm{~m}$ of sediment at the site included well defined sequences of siliciclastic (sand, silt, and clay) and carbonate, which was determined to be well within the regional geologic context. Critical 


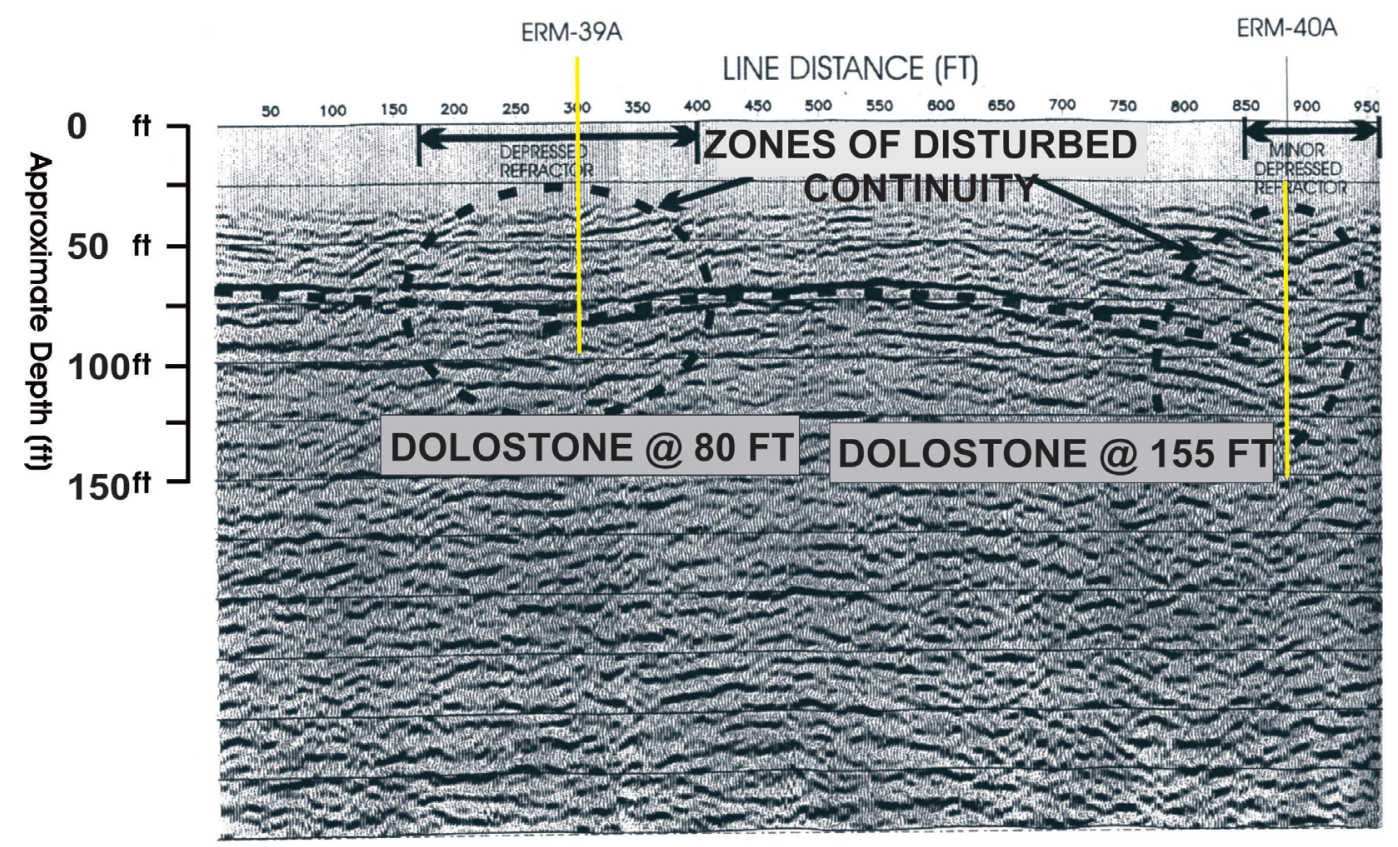

ANOMALOUS SEISMIC REFLECTION SECTION - LINE 15

Figure 10. Example of an interpreted $P$ wave reflection section and observed geophysical anomalies (Upchurch et al., 1999).

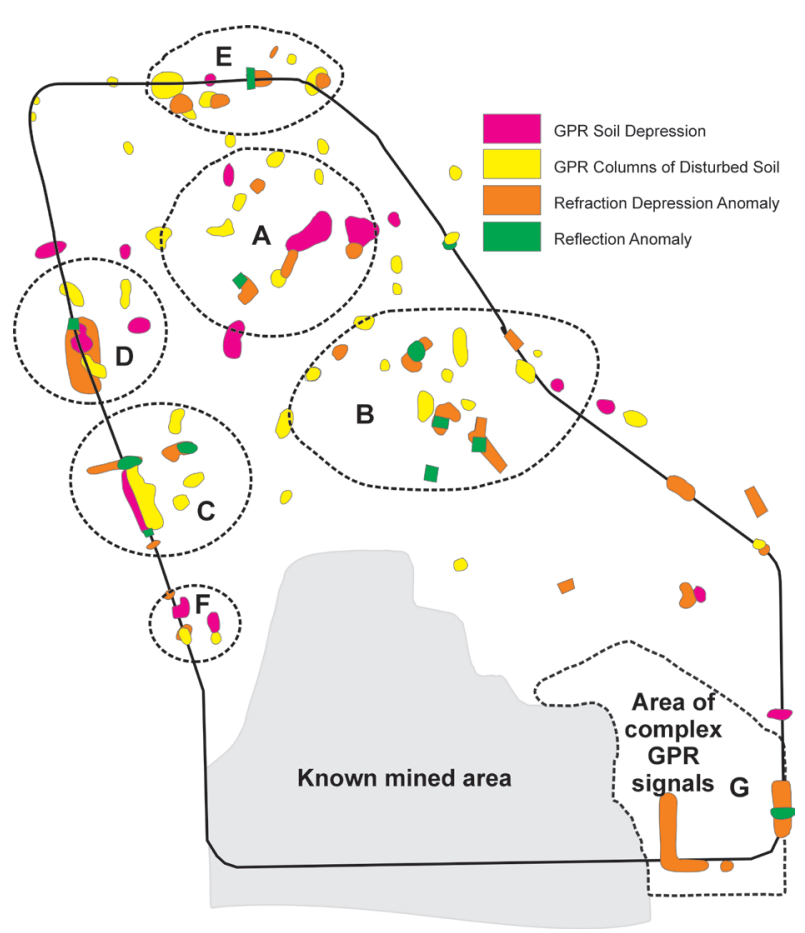

Figure 11. Identified geophysical anomalous condition areas $A$ through $G$ within the reservoir footprint. (Upchurch et al. 1999).

geologic observations which have a considerable influence in the photolinear interpretation include the leached zone and the epikarst. Both are discussed below.

\begin{tabular}{|l|c|c|}
\hline Exploration Type & $\begin{array}{c}\text { Number of } \\
\text { Explorations }\end{array}$ & $\begin{array}{c}\text { Total } \\
\text { Linear } \\
\text { Meters }\end{array}$ \\
\hline Rotary/Wash Borings & 165 & 4,084 \\
\hline $\begin{array}{l}\text { Cone Penetrometer Test } \\
\text { Soundings }\end{array}$ & 109 & 975 \\
\hline $\begin{array}{l}\text { Flat-plate Dilatometer } \\
\text { Soundings }\end{array}$ & 18 & 145 \\
\hline Auger Borings & 60 & 274 \\
\hline Trenches & 4 & 442 \\
\hline Piezometers & 41 & N/A \\
\hline $\begin{array}{l}\text { Aquifer Performance Test } \\
\text { Soundings }\end{array}$ & 2 & N/A \\
\hline $\begin{array}{l}\text { Borehole Hydraulic Con- } \\
\text { ductivity Tests }\end{array}$ & 17 & N/A \\
\hline
\end{tabular}

Table 1. Geologic engineering explorations and testing completed

From near the end of the Miocene through the Pliocene, sea level fluctuated greatly in this region of Hillsborough County, with long weathering events, erosion, and pedogenesis during the lower sea stands. Phosphoriterich and clay-rich sediments were chemically altered during these episodes of extensive weathering.

The calcium phosphate mineral, carbonate fluorapatite, was leached, and the calcium moved downward in 


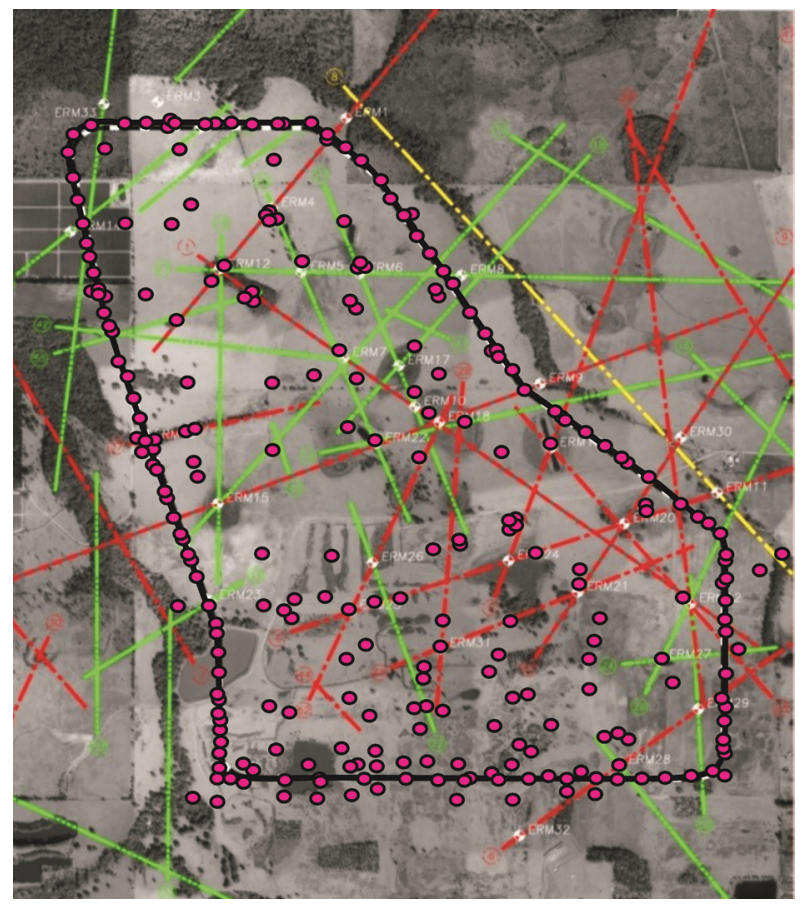

Figure 12. Location of subsurface testing sites (red circles; modified from Upchurch et al. 1999).

the stratigraphic column to contribute to formation of calcium carbonate cements in underlying strata. The phosphate was partly transported downward, but some remained to combine with aluminum, iron, and other weathering products in the resulting zone. The residual minerals formed by recombination of phosphate with other cations include wavelite, millisite, crandallite, and other aluminum phosphate minerals. This leaching process, therefore, formed two zones: a leached, aluminum-phosphate-rich zone at the top and a calciumphosphate-enriched zone below. In mining terminology, the upper zone has been termed the "leached zone" (Carr and Alverson 1959). Carr and Alverson (1959) also showed that the dominant clay mineral in the strata being weathered was at least partially altered from montmorillonite to kaolinite. The resulting leached zone is, in fact, a fossil soil zone, or paleosol.

The leached zone is a portion of the thicker aluminum phosphate zone that contains aluminum phosphate minerals and is dominantly white to light tan in color or sediment colors developed as a result of the leaching of iron-containing minerals. The zone can be located in either the upper clayey sand unit of the Bone Valley Member, the upper clayey sand and top of the lower phosphorite unit of the Bone Valley Member, or both units of the Bone Valley Member plus the top of the Peace River Formation (Scott 1988). Carr and Alverson (1959) provide criteria for recognition of the aluminum phosphate zone, including: (1) vesicular-like texture;
(2) secondary cements; (3) white color; (4) low relative density; and (5) indurated or friable character.

The leached zone is present at the reservoir site and is a very critical component in the ground-truthing the photolineament assessment. At the site, the leached zone averages $4 \mathrm{~m}$ in thickness, with a range of 0 to $12 \mathrm{~m}$. The thickness data indicate that the zone thins to the south, which would have resulted in higher phosphate values than in the north. The paleosol can be physically recognized by: (1) decreasing relative sediment strength (low penetration resistances measured during standard penetration testing); (2) weathered limestones; and (3) calcium carbonate-cemented sand, silt, or clay beds.

There are two patterns of thickened leached zone. First, in the center of the northern half of the site, there is some thickening of the leached zone. This coincides with a depression in the leached zone surface and the thicker overlying sediments. It is apparent that this area of the site was a region of enhanced weathering and pedogenesis, which contributed to the wetlands present at the land surface. There are also several locations of thickened leached zone in the small stream channels that exit the project site to the north and west. Again, this suggested that the paleosol surface represented by the top of the leached zone had drainage ways that were locations of enhanced weathering. These drainage ways have apparently redeveloped on the modern landscape, because of continual leaching (Upchurch et al. 2015).

The limestone and dolostone encountered below the leached zone within the Miocene Hawthorn Group clayrich sediments were weathered in varying degrees via non-uniform dissolution and had an observable epikarst. Epikarst is the zone of weathering at the upper surface of a limestone stratum. Weathering of limestone results in development of rubble, fine-grained carbonate-rich silt, and clay, karren (including pinnacles and valleys in the limestone rock surface), and other features. Epikarst is frequently associated with losses of drilling fluid circulation, low penetration resistance (weight of rod or hammer events during standard penetration testing) and recovery of gravel-sized particles of rock. The epikarst can occur at the land surface or be buried under later sediments. Raveling of soil or sediments into the voids within the epikarst formation can lead to sinkhole formation, but in most cases, there is no evidence of ongoing or contemporaneous raveling, and the epikarst is not synonymous with sinkhole formation. The depth to these carbonate units varied due to the irregular surface of the epikarst, but on average was approximately $10 \mathrm{~m}$ BLS.

As an example of the results of subsurface testing as compared with the geophysical interpretations, Figure 
13 is a boring-derived subsurface cross-section. Note the borehole results clearly show increased depth (depth is nearly double the normal dolostone depth) to the dolostone layer on one location, because of what appears to be a paleo-sinkhole.

Upon completion of the subsurface exploration program, the photolinears were again reviewed and any photolinear with a vertically extensive geophysical or stratigraphic signature was considered a fracture trace. All other unconfirmed photolinears were not considered further.

\section{Post Hoc Photolinear Analysis}

Table 2 presents the results of the post hoc review of photolineament verification at the site. The results were somewhat surprising given the confidence that we expressed in photolineament analysis prior to commencement of the investigation.

Approximately 48 percent of the photolineaments and potential karst features were confirmed as representing bedrock fractures or sinkholes. Of these, we had to adjust the apparent lengths of the photolineaments in the majority (Table 2), generally because the fracture was shorter than predicted by the photolineament.

The photolinear features that were not found to have deep subsurface indicators are apparently a result of conditions that are restricted to the marine terrace sand and/or paleosol. Upchurch et al. (2015) discuss the origins of the shallow depressions associated with the paleosol.

\section{Discussion and Conclusions}

The photolinear features that were confirmed as bedrock fractures by means of the geophysical surveys appear to reflect vertical fractures in the underlying carbonate rock, in many cases accompanied by depressions in the top of the leached zone or underlying strata. For the most part, the surface expressions of verified photolineaments reflect soil and sediment deposition and minor compaction into depressions in the leached zone and top of the upper siliciclastic and/or carbonate facies of the Miocene Hawthorn Group (Upchurch et al. 2015). Buried relict stream channels and other topographic features developed on the leached zone were also detected.

\begin{tabular}{|l|c|}
\hline Outcome & Percentage \\
\hline $\begin{array}{l}\text { Photolineaments confirmed as } \\
\text { fracture traces, no modifications of } \\
\text { delineation required }\end{array}$ & $5.8 \%$ \\
\hline $\begin{array}{l}\text { Photolineament confirmed as a } \\
\text { fracture trace, length was shorter than } \\
\text { predicted }\end{array}$ & $32.7 \%$ \\
\hline $\begin{array}{l}\text { Photolineament confirmed as a } \\
\text { fracture trace, length was longer than } \\
\text { predicted }\end{array}$ & $9.6 \%$ \\
\hline $\begin{array}{l}\text { Photolineament was not confirmed to } \\
\text { represent a fracture trace }\end{array}$ & $57.7 \%$ \\
\hline
\end{tabular}

Table 2. Results of the post hoc evaluation of photolineament accuracy.

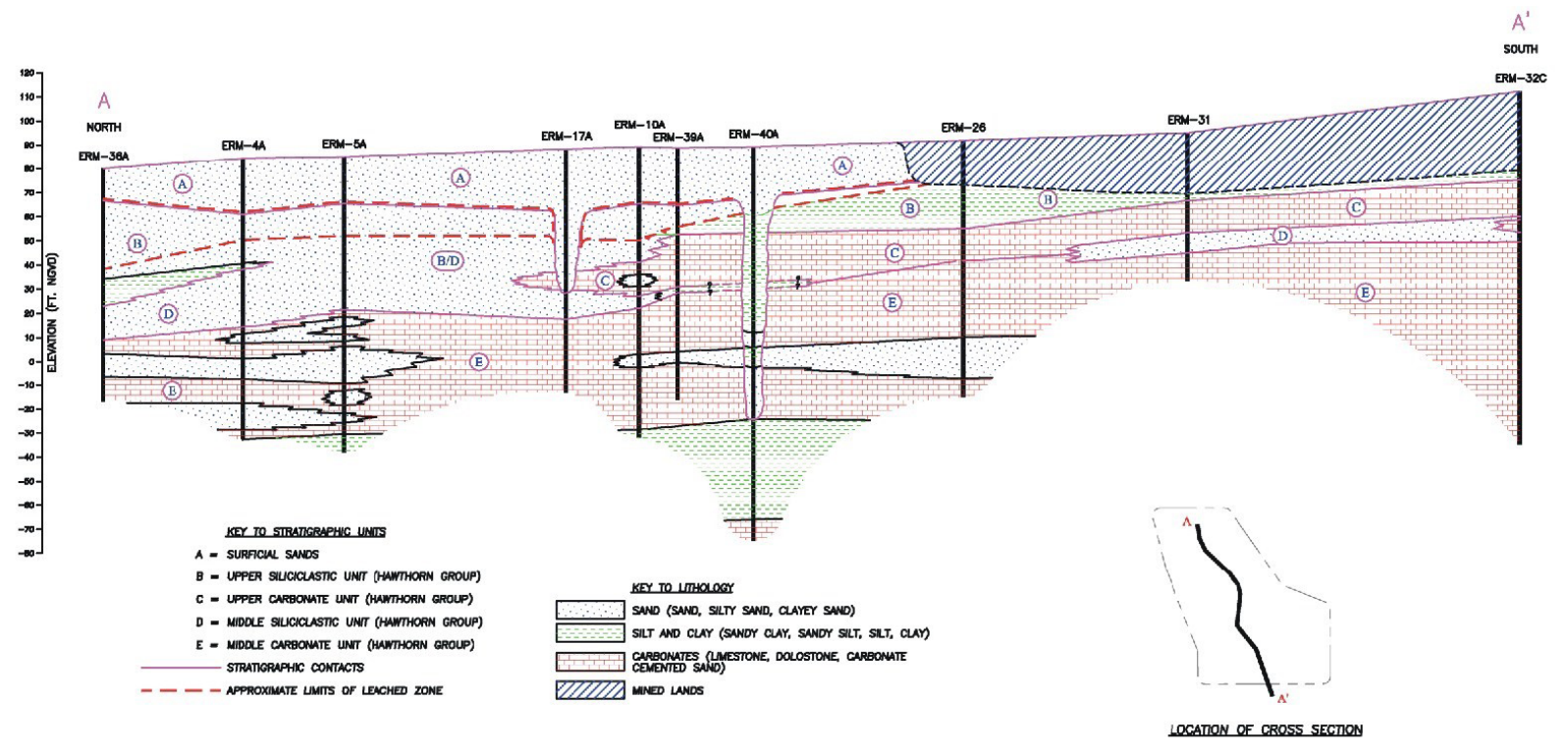

Figure 13. North-Northwest/South-Southeast geologic fencepost diagram (Upchurch et al., 1999). 
Minor differential settlement in the Plio-Pleistocene paleosol features resulted in some of the photolineaments, which were not related to fracturing or karst in the underlying carbonate strata (Upchurch et al. 2015). One apparent paleo-sinkhole feature within the original alignment of the berm was considered of sufficient importance that the berm was realigned to avoid it. Otherwise, the paleo-karst features did not provide geologic or geotechnical evidence for reactivation and were found to be competent for reservoir development without a liner or other leakance prevention system. The reservoir has been in use for over a decade without incident, and leakage from the reservoir is less than predicted. To date, no sinkholes have developed at the site.

In respect to the photolinear interpretation (Figure 3 ), the analysis was conservative in that all potential photolineaments were identified. All points where a photolinear feature crossed the embankment were investigated with GPR and seismic refraction. Seismic reflection was employed if anomalies were detected by seismic refraction surveying. Because geophysical exploration was combined with subsurface geotechnical testing along the embankment centerline and in geophysical anomalies, the photolinear verification process was considered extensive and thorough.

It is important to note that even photolinears presented on Figure 3 with high levels of relative confidence (i.e., multiple, strong visual indicators of linear features) were found to have no or very weak subsurface indications of the causes of the photolinears. Many of the photolineaments $(32 / 55$ or 58 percent) were not confirmed by geophysical or subsurface exploration. Most features that have been confirmed by geophysical exploration are restricted in their lengths when compared to the original photolinear analysis. This post hoc review of the results of verification of photolinear features by geophysical and subsurface explorations demonstrates the fallacies of assuming that all photolinears represent vertical bedrock fractures in a covered karst terrain.

Regional and local photolineament analyses are valuable as a first approximation of the possible presence of bedrock structures such as vertical fractures in covered karst. However, one cannot rely on a correlation between photolinear features and fracture traces in covered karst areas without field verification. The results of our case study are consistent with the published literature (i.e., Wheeler 1983) in showing that ground truthing using other kinds of data is necessary to verify the correspondence between photolineaments and vertical fractures and karst features.
It is also important to point out that hydraulic pathways (i.e., cavernous porosity, solution-enlarged bedding planes, etc.) may exist in covered karst terrains. Therefore, the absence of verified fractures may not indicate low hydraulic conductivities of the underlying carbonate strata.

\section{References}

Dobecki TL, Upchurch SB. 2010. A multi-level approach to site characterization - C.W. Bill Young Regional Reservoir, Hillsborough County, Florida. In: Proceedings of the Environmental and Engineering Geophysical Society, Application of Geophysics to Engineering and Environmental Problems (SAGEEP). p. 8.

Carr WJ, Alverson DC. 1959. Stratigraphy of Middle Tertiary rocks in part of west-central Florida. U.S. Geological Survey Bulletin 1092.

Lattman LH. 1958. Technique of mapping geologic fracture traces and lineaments on aerial photographs. Photogrammetric Engineering 24: 568-576.

Lattman LH, Matzke RH. 1961. Geological significance of fracture traces. Photogrammetric Engineering 27:435-438.

Lattman LH, Parizek RR. 1964. Relationship between fracture traces and the occurrence of groundwater in carbonate rocks. Journal of Hydrology 2:73-91.

Littlefield JR, Culbreth MA, Upchurch SB, and Stewart MT. 1984. Relationship of modern sinkhole development to large-scale photolinear features. In: BF Beck (ed.). Sinkholes: Their geology, engineering \& environmental impact, Rotterdam, B.A. Balkema, pp. 189-195.

Puri HS and Vernon RO. 1964. Summary of the geology of Florida and guidebook to the classic exposures, Florida Geological Survey Special Publication No. 5 (revised).

Scott TM. 1988. The lithostratigraphy of the Hawthorn Group (Miocene) of Florida. Florida Geological Survey Bulletin 59.

Scott TM, Campbell KM, Rupert FR, Arthur JD, Green RC, Means GH, Missimer TM, Lloyd JM, Yon JW, Duncan JG. 2001. Geologic map of the State of Florida. Florida Geological Survey Map Series No.146.

Upchurch SB, Dobecki TL, Daigle DM. 1999. Geological, hydrogeological, and geophysical investigation. In: Law Engineering Services et al. Geotechnical Site Characterization Report Tampa Bay Regional Reservoir, Volume I, Section 3. p. 76 .

Upchurch, S.B., Littlefield JR Jr. 1988. Evaluation of data for sinkhole-development risk models. 
Environmental Geology and Water Science, 12:135-140.

Upchurch SB, Scott TM, Alfieri MC, Dobecki TL. 2015. Shallow depressions in the Florida Coastal Plain: Karst and pseudokarst. In: Doctor DH, Land L, and Stephenson JB (eds.), Sinkholes and the Engineering and Environmental Impacts of Karst, Proceedings of the 14th Multidisciplinary Conference, Rochester, MN, National Cave and Karst Research Institute Symposium 5, pp. 231240.

Wheeler RL. 1983. Linesmanship and the practice of linear geo-art: Discussion and reply. Bulletin, Geological Society of America, 94:886-888. 